\title{
The Ethnobotany of Abui's Homegardens and its Potentiality to Support Rural Tourism Development in Alor, Indonesia
}

\author{
Isak Feridikson Alelang ${ }^{1 *}$, Luchman Hakim², Jati Batoro ${ }^{2}$ \\ ${ }^{1}$ Master Program of Biology, Faculty of Mathematics and Natural Sciences, University of Brawijaya, Malang, Indonesia \\ 2Department of Biology, Faculty of Mathematics and Natural Sciences, University of Brawijaya, Malang, Indonesia
}

\begin{abstract}
The aim of the research is to explore the value of homegardens at Abui community in Takpala Village, Alor Island, as a basis of rural tourism development. The value of home gardens was assessed in the perspective of local people's culture. Therefore, ethnobotanical assessment with Index of Cultural Significance (ICS) was implemented. Data was collected through field observation and interviews to local community. Survey was done in 15 houses in Takpala settlements by identifying plant species in homegardens area. Interviews were performed to generate information regarding flora benefits in the daily life of local people in Takpala. Result of the study shows that homegarden has an important role among Abui community, especially in cultivating numerous plant species for daily life. Homegarden has its potentiality to be introduced as part of the tourism development attraction in Takpala Village.
\end{abstract}

Keywords: conservation, economic plant, rural tourism, Timor homegarden.

\section{INTRODUCTION}

Indonesia has abundance natural and cultural resources, in which many of these resources have been promoted and used in tourism industry. Indonesia is also home to numerous spectacular landscapes which are unique and many of them has special relationship with its local culture [1]. According to tourism statistical data released by Ministry of Tourism in 2017, number of international tourism increase significantly. In 2014, number of tourist was recorded 9,435,411 and increase to 10,406,759 in 2015. In 2016 international tourist arrival was recorded $12,023,971$ [2]. International tourist arrivals and tourism activity contribute to the national and regional economic earning. Scholars point out that tourism has significant role in development and therefore it is reasonable to support more tourism sector development. It is especially important to increase the local community's economic development.

Alor Island in East Nusa Tenggara Province is naturally and culturally rich in term of tourism resources. In the perspectives of tourism development, Alor close to the issues of less developed regions, indicated by lack of tourism infrastructure and poor of human resources in tourism. In the situation where traditional aspect of life is dominant, Alor represent a unique tourism destination among western people. Alor

\footnotetext{
* Correspondence address:

Isak Feridikson Alelang

Email : isacalelang@gmail.com

Address : Dept. Biology, University of Brawijaya, Veteran Malang, 65145
}

is home to indigenous community called Abui, in which many of them live in rural areas in Alor. Abui community is one of the oldest tribes in Alor Island that maintain the authenticity of culture than other tribes on the island. The living place of Abui community that is often visited by tourists is Kampung Takpala. Takpala is a traditional village with its unique landscape and its citizens uphold the customs and culture. There are relics of ancestors, rows of traditional houses and homegarden as a unity of tourist attractions.

Local people in rural area in Alor live in traditional ways, create a balance life between human and nature in harmony. The sustainable living system has been promoted and implemented as a part of the living system. Knowledge to manage space has produce numerous types of ecosystem that are important to support living system in remotes area. Homegardens is one of the important form of land uses in Abui community, which its role has been considered important. Homegarden arrangement is the representative of local knowledge to enhance the living sustainability among local people, especially in term of the sustainability of food supply $[3,4]$.

Homegardens were widely explored to identify its benefits for food security, public health and biodiversity conservation. The high biodiversity of homegardens provides numerous resources for consumable plant, namely plant for human food, medicinal and cultural usage [5]. In tropical countries, homegarden often shows complex vertical and horizontal structure. In many case, the homegardens related with local 
culture [6]. Homegardens management and people perception to the plants in homegardens system produces unique landscapes [7]. Many of them are unique and has potentiality to be integrated in the tourism development.

The homegarden in Takpala community has its potentiality as tourism resources. In some countries, the homegardens has significant contribution in visual aspect, especially in creating beautiful landscape. The development and integration of homegarden in Takpala especially important to support the development of settlement in Takpala as tourism destination. The Takpala settlementst contain 15 traditional houses with its homegardens as an integral part of the traditional ecosystem. The aims of the research is to explore the value of homegardens at Abui community for potential resources of rural tourism development.

\section{MATERIALS AND METHODS Study Area}

Field research was done in the Abui community, especially in local settlement in Takpala Traditional Village. Administratively, this area belongs to Lembur Barat Village, Alor Tengah Utara Sub-regency, Alor Regency in East Nusa Tenggara Province. The local settlement located at the slope of Mt. Abui at elevation 131 $\mathrm{m}$ asl, surrounded by forest and plantation (Fig. 1). The local people of Kampung Takpala belongs to the Abui tribal community and considered as one of the old tribal community in Alor Island. The majority of local people was farmers that depend on the forest resources, plantation and hunting.

\section{Data Collection}

Field survey was conducted at 15 units of house and its homergadens. In each visited garden, flora identification was implemented by direct observation and identification. The principal characteristics of plant identification is based on morphological characters. Plant specimen collection was done only when the plant is unidentified by direct observation.

The sample was collected as herbarium material for further identification in Laboratory of Plant Taxonomy in University of Brawijaya (Malang, East Java) and Purwodadi Botanical Garden in East Java. In each garden, an interviews was conducted to the owners to describe the types of uses of each plant in their homegardens.

\section{Data Analysis}

The use of numerous plant species in homegardens environment was evaluated using basic formula of Index of Cultural Significance (ICS) following the formula $[8,9]$.

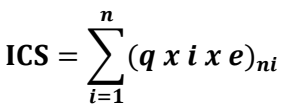

Since some plant has many function, the formula was modified into:

$\mathrm{ICS}=\sum_{i=1}^{n}\left(q_{1} x i_{1} x e_{1}\right)_{n 1}+\left(q_{2} x i_{2} x e_{2}\right)_{n i} \ldots+\left(q_{n} x i_{n} x e_{n}\right)_{n i}$

Description:

ICS: total use value of particular species from 1 to $n$ representing the last described use.

$Q$ : Quality value, was calculated following the important value of plant in daily life of local community. It is assessed following scores: 5 (main staple food), 4 (secondary food or primary materials), 3 (other foods or secondary materials or medicinal plant), 2 (plant for ritual, mitology and other usage), 1 (use/mere recognition).

i : Intensity value, shows the intensity of plant, with: 5 (very high intensity), 4 (high intensity), 3 (moderate intensity), 2 (low intensity), 1 (rare or very low in intensity of use).

e : Exclusivity value, conditions: 2 (the most favored plants that become the main preferences and could not be replaced); 1 (the favored plants but could be replaced by other species of plant) and 0.5 (the beneficial plants that become the secondary preferences).

\section{RESULTS And DISCUSSION}

Homegardens as Component of Settlement

Homegardens is a principal component of traditional landscape in Takpala. The roles of homegardens are numerous, including sites for cultivating some plant species which are consumed in daily lives and sites to grow medicinal plants species. Physically, homegardens located at slope land, ranges from $5-40^{\circ}$ lead local people adaptation to manage land by following land contour and establishing terrace. Terrace structure was strengthened by stone and plant (Fig. 2). Terrace was design to provide space to cultivate numerous plants and reduce soil erosion. Therefore, terrace is the useful methods in land conservation and protection against rainfall water flows [10]. 


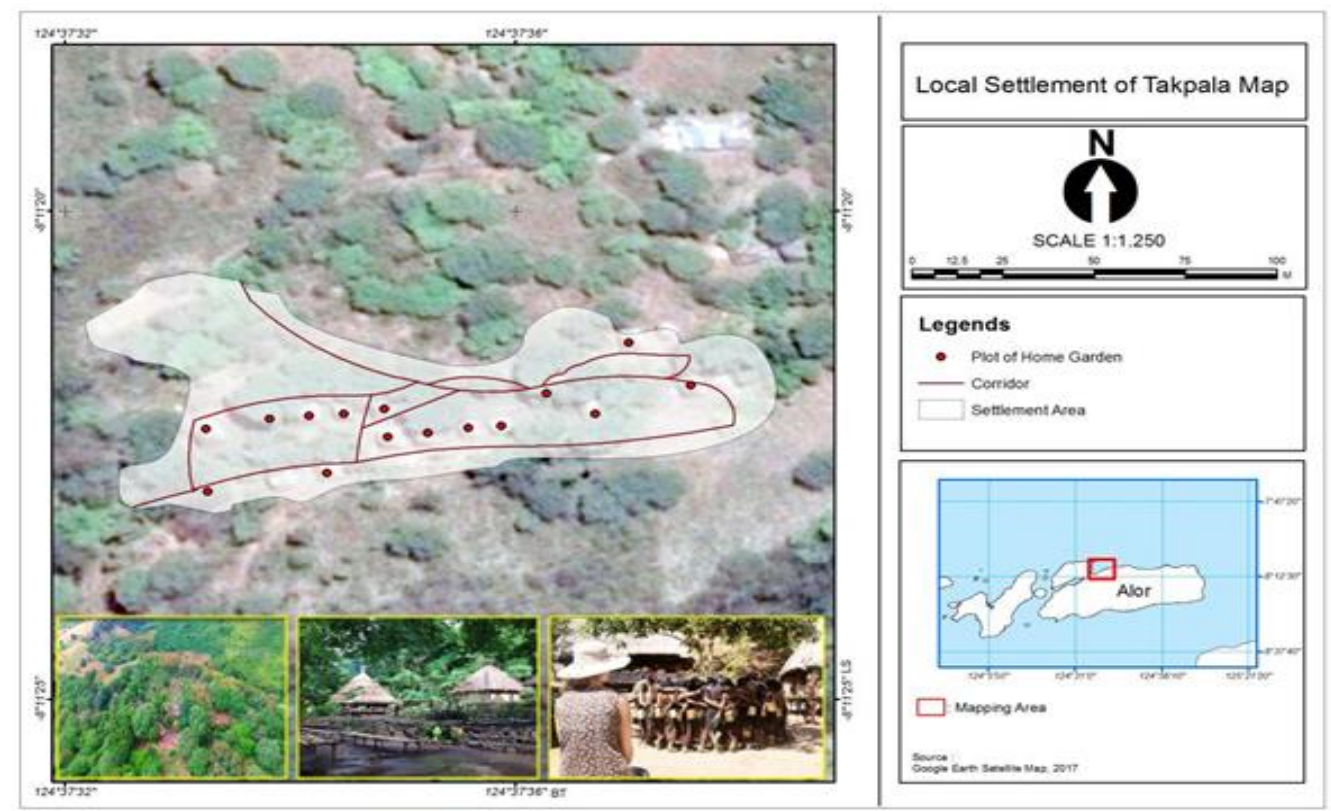

Figure 1. Map and Situation of Takpala Local Settlement in Alor Island, East Nusa Tenggara

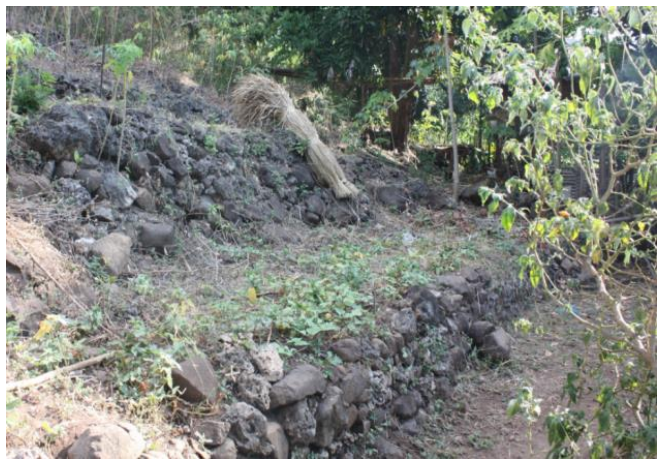

Figure 2. Terrace Structure in Homegardens

The homegardens has numerous sites. Many of them was set up without border. The land of house and homergardens ownership often has stone and vegetation border. The length of homegarden from east to west was about 2-4 meter and the length of gardens from north to south has more length. In some homegardens, there are public toilet and animal's cage in the backyards area. Homegarden with large area often has traditional rest area build from bamboo (locally called liktaha).

Takpala settlement area located at the semiarid regions, with length of 7-8 months dry season in a year. Length of rainy season was limited. This situation influence the homegarden management, in which intensive garden management only optimum in rainy seasons. It is often started at October. The management of homegardens was practiced following traditional mechanism. There are no modern tools and equipment was practiced, including chemical pesticides and fertilizer application. Weeding was done in homegarden regularly in free time after farming activity. Crops cultivation was done in traditional manner. Homegarden is miniature of farmlands. Many plant species cultivated, including staple food, medicinal plant and ornamental plant.

\section{The Value of Species}

The value of species as calculated using ICS was shown in Table 3. Areca catechu (Arecaceae) has the highest ICS value (ICS = 112). Areca catechu, is locally called pinang, in the perspective of Abui community is important plant. It is not staple food, but it is culturally important. There are tradition among local people (Abui community) to consume pinang (areca nut). Abui traditionally called it as fu takey or mamasiri, which was done in daily life without limitation time. Pinang consumption is basically local tradition and Adat symbol. It is not only practiced in Abui community in Alor, but it is widely practiced among local community in Nusa Tenggara Islands and eastern Indonesia. Besides palm fruit, areca palm has numerous benefits among local people in Takpala. The bark of tree was proceed as a water canal and civil construction material. Bark also used as fuel wood. The midrib of areca catechu was used as food package and other package purposes, and handicraft. Areca catechu was introduced in homegarden especially to countermeasure land erosion. 
Abui's Homegardens to Support Rural Tourism Development in Alor,

East Nusa Tenggara (Alelang et al.)

The second species with highest ICS was Cocos nucifera L. (coconut), with ICS value 109. It is widely recognized that coconut is important plant for numerous purposes. Coconut has economic value and becomes the important crops plant in many area in developing countries. $[11,12]$. Cocos nucifera $\mathrm{L}$. has high cultural and social value among local community in Abui. This plant was used for numerous purposes to support daily life activity of local community of Abui. The water of fruit and young coconut often consumed as beverages. The coconut milk was used as medicinal material, cooking and components of washing hair in traditional healing treatment. The steam was used for numerous purposes, especially for civil materials. Many parts of coconut are also widely used as fuel wood.

Zea mays (Poaceae) is the third important species with high value of ICS. Corn is the main food for local people in Alor, including community in Takpala. Corn is widely cultivated in homegardens. Corn is a main sources of carbohydrates. In many events, corn was cooked as food in traditional ceremony and religious activity. The midrib of corn was used as cattle fodder.

Rice, Oryza sativa (Poaceae) has been recognized as one of the culturally important species among Abui community. Some households in Takpala cultivate rice in homegardens in limited amount. Interestingly, some informant in this study state that people cultivate rice in small population in homegardens just to meet their hobby, increase the beauty of home gardens, and as miniature of paddy upland field. Widely, rice is important carbohydrate sources in Indonesia, but in semiarid and arid regions, rice often replace by corns as a staple food. Traditionally, rice cooked and served using traditional dish created from leaf of lontar pal (Borassus flabellifer). It is especially found in cultural events and religious ceremony in Abui community in Takpala.

Coffee (Coffea sp) was also identified as culturally important species among Abui community. Coffee is the common drink in Indonesia, and it is widely cultivated in Indonesia [13]. Besides consumed in daily life, coffee was also involved in many cultural and social activity. Among Abui community in Takpala, coffee is important beverages and the tradition to drink coffee is culturally transmitted from generation to generation through cultural and social activity. In Takpala, coffee is also use as medicinal plant. The wood of coffee is also used as materials for handicraft and fuel wood.

Species with high ICS shows the important of species in the daily life of community in Takpala. Depending on the situation and condition, the value of ICS and species rank can be changes. This phenomena is basically influenced by changes of community perception and appreciation to species, especially in species usages.

\section{Implication for Rural Tourism Development in Takpala Traditional Village}

SWOT analysis confirm that there are numerous internal and external aspect for the design establishment of homegarden conservation (Table 2). In the perspectives of tourism development, Homegarden is basically can be introduced as part of the tourism attraction development. Homegardens' of Abui community is crucial ecosystem component in human settlements in Takpala. Homegardens management was done in traditional approach, and overall, it is represent the cultural value of local people in Takpala.

Table 1. Plant Species with Highest ICS Value

\begin{tabular}{cllll}
\hline No & Local name (Indonesia) & Scientific name & Family & ICS \\
\hline 1 & Pinang & Areca catechu & Arecaceae & 112 \\
2 & Kelapa & Cocos nucifera L. & Arecaceae & 109 \\
3 & Jagung & Zea mays & Poaceae & 102 \\
4 & Padi & Oryza sativa L. & Poaceae & 100 \\
5 & Kopi & Coffea sp. & Rubiaceae & 91 \\
6 & Pepaya & Carica papaya L. & Caricaceae & 88 \\
7 & Bambu & Bambusa sp & Poaceae & 84 \\
8 & Pisang kepok & Musa paradisiaca L. & Musaceae & 78 \\
9 & Sirih & Piper betle L. & Sapindaceae & 78 \\
10 & Kesambi & Schleichera oleosa & Poaceae & 75 \\
11 & Bambulicin & Bambusa vulgaris & Zingiberaceae & 72 \\
12 & Kunyit & Curcuma domestica L. & Anacardiaceae & 66 \\
13 & Manggakelapa & Mangifera indica & Moraceae & 66 \\
14 & Nangka & Artocarpus heterophyllus & Mimosaceae & 64 \\
15 & Lamtoro & Leucaena leucocephala L. & & 62 \\
\hline
\end{tabular}


Table 2. SWOT Analysis of Homegarden Conservation as a Basic for Tourism Development in Takpala

\begin{tabular}{|c|c|c|}
\hline Factors & Strengths (S) & Weaknesses (W) \\
\hline External & $\begin{array}{l}\text { 1. Attractive and beauty landscape with } \\
\text { its component (i.e. mesbah, mesang, } \\
\text { and traditional house, historical } \\
\text { resources) } \\
\text { 2. Local knowledge in homegarden } \\
\text { management. } \\
\text { 3. Homegarden contains } 133 \text { species } \\
\text { and } 55 \text { family of plant species } \\
\text { 4. Art and cultural assets which area } \\
\text { attractive to tourist } \\
\text { 5. Local community has local } \\
\text { knowledge to use numerous plant } \\
\text { species for numerous purposes. } \\
\text { 6. Geographically, Takpala is accessible, } \\
\text { close to airport, road and close to } \\
\text { other tourism attraction } \\
\text { 7. Fresh water is available to support } \\
\text { local community and tourist. }\end{array}$ & $\begin{array}{l}\text { 1. Conflict in land ownership. } \\
\text { 2. Poor information on history and } \\
\text { tourism attraction } \\
\text { 3. Poor of local appreciation in } \\
\text { historical building preservation, } \\
\text { environment cleanliness } \\
\text { 4. Potential conflict among local } \\
\text { people caused by high } \\
\text { competition in tourism industry. } \\
\text { 5. Lack of ornamental plant and } \\
\text { indigenous species in } \\
\text { homegarden. } \\
\text { 6. Poor of tourism infrastructure } \\
\text { and tourism information } \\
\text { 7. Water debit decrease in dry } \\
\text { season. }\end{array}$ \\
\hline Opportunities (0) & Strategy S/O & Strategy W/O \\
\hline $\begin{array}{l}\text { 1. Global tourism growth. } \\
\text { 2. Global conservation growth. } \\
\text { 3. Global attention to the local culture } \\
\text { and indigenous landscape conserva- } \\
\text { tion. } \\
\text { 4. Indonesian government policy to } \\
\text { increase development in remotes area. }\end{array}$ & $\begin{array}{l}\text { 1. Designing Traditional Village of } \\
\text { Takpala as a sites for cultural and } \\
\text { heritage tourism. } \\
\text { 2. Promoting Traditional Village of } \\
\text { Takpala as an ideal sites for } \\
\text { biodiversity research, and edu- } \\
\text { tourism development. } \\
\text { 3. Promoting vegetables, fruit and } \\
\text { many crop products and enhancing } \\
\text { the local capacity to produce } \\
\text { numerous food based on local } \\
\text { resources. } \\
\text { 4. Enhancing community involvement } \\
\text { in the implementation of rural } \\
\text { tourism in Takpala. } \\
\text { 5. Managing plant species, including } \\
\text { medicinal plant and crops as an } \\
\text { interesting attraction for tourism } \\
\text { development. }\end{array}$ & $\begin{array}{l}\text { 1. Reconciling all of the community } \\
\text { member and create } \\
\text { commitment for development. } \\
\text { 2. Inviting researcher to explore } \\
\text { the history of Takpala. } \\
\text { 3. Collaboration with government } \\
\text { and all stakeholders to promote } \\
\text { environmental } \\
\text { sanitation, etc. } \\
\text { 4. Introducing and increasing } \\
\text { number of indigenous plant } \\
\text { species in homegarden. }\end{array}$ \\
\hline Threats/T & Strategy S/T & Strategy $\mathrm{W} / \mathrm{T}$ \\
\hline $\begin{array}{l}\text { 1. Lack of government involvement in } \\
\text { tourism planning and management in } \\
\text { Takpala. } \\
\text { 2. Rarity of building material to enhance } \\
\text { the sustainability of local buildings. } \\
\text { 3. Less availability of seeds of numerous } \\
\text { native and indigenous plant tree } \\
\text { species. } \\
\text { 4. Rapid modernization changes local } \\
\text { cultural organization and local value. }\end{array}$ & $\begin{array}{l}\text { 1. Developing communication among } \\
\text { local movement-local community } \\
\text { and private sector to support } \\
\text { tourism development. } \\
\text { 2. Strengthening control mechanism on } \\
\text { the uses of natural resources, } \\
\text { especially forest resources. } \\
\text { 3. Strengthening local wisdom to } \\
\text { manage homegardens. } \\
\text { 4. Promoting local culture of Abui in } \\
\text { many activity, especially in gardening } \\
\text { and farming. }\end{array}$ & $\begin{array}{l}\text { 1. Promoting collaboration } \\
\text { between stakeholders and local } \\
\text { community } \\
\text { 2. Strengthening the networking in } \\
\text { the traditional village of Takpala. }\end{array}$ \\
\hline
\end{tabular}

Managing homegarden properly is important in the perspectives of tourism destination and attraction in Takpala. In this aspect, homegardens has significant role in tourism development. First, it is related to the effort to improve environmental quality. Second, homegarden as media for education, and third, homegardens provides numerous goods to support tourist needs, especially for food needs.

The role of home garden to improve environmental quality comes from the fact that homegarden contains numerous plant. Besides important to provide consumable materials, homegarden able to improve environmental 
Abui's Homegardens to Support Rural Tourism Development in Alor,

East Nusa Tenggara (Alelang et al.)

quality. There are numerous beautiful plants which are contribute in beauty landscapes. Many plant are related to the cultural, and it is rarely found in other place. These become the unique component in indigenous landscape of Takpala village. Biodiversity and unique species characters in building homegarden can be introduce to the tourism accommodation in Takpala.

The diversity of species in homegardens and its cultural value is the interested object for education which are important in conservation programs. As far, there are no scenario to involve pant diversity into tourism program. Ecotourism often paid attention to the local biodiversity recognitions part of the education program.

The homegardens provides numerous fruit, vegetables, etc. which are important in supplying and providing numerous local menu. It is especially important in the development of gastronomy or culinary tourism development based on local materials.

\section{CONCLUSION}

Homegarden in Takpala exist as a human activity to modify environment as space to provide numerous goods and sources to support households daily life needs. Homegarden in Takpala contains 133 species and 55 family of plant species. The species usages mostly for cultural activity, food, construction material, fuel, medicinal plants, beverages, landscape beauty, food wrap, and handicraft. ICS and species rank can be changes influenced by changes of community perception and appreciation to species, especially in species usages.

\section{REFERENCES}

[1] Putri, W. K., L. Hakim and J. Batoro. 2016. Ethnobotanical survey of home gardens in Pandansari and Sumberejo to support ecotourism program in Bromo Tengger Semeru National Park, Indonesia. International Journal of Research Studies in Agricultural Sciences 2(1), 6-12.

[2] Ministry of Tourism Republic of Indonesia. 2017. Statistik wisatawan mancanegara, Available at: http://www.kemenpar.go.id /asp/detil.asp. ?c=110\&id=3139.

[3] Solossa, A. H., Soemarno, I. R. Sastrahidayat and L. Hakim. 2013. Home gardens of the local community surrounding Lake Ayamaru, West Papua Province, and its consequences for tourism development and lake conservation. Journal of
Biodiversity and Environmental Sciences 3(1), 1-11.

[4] Hakim, L. 2014. Etnobotani dan manajemen kebun pekarangan rumah: ketahanan pangan, kesehatan dan agrowisata. Selaras. Malang.

[5] Mekonnen, A., A. Mekuria and A. Zemede. 2014. The role of homegardens for in situ conservation of plant biodiversity in Holeta Town, Oromia National Regional State, Ethiopia. International Journal of Biodiversity Conservation 6(1), 8-16.

[6] Batoro, J., S Indriyani and B. Yanuwiadi. 2017. Ethno-ecology of Komplangan Field of the Bromo, Tengger, and Semeru Area in East Java: a qualitative approach. Biosaintifika Journal of Biology and Biology Education 9(1), 41-48.

[7] Hakim, L. and N. Nakagoshi. 2007. Plant species composition in home gardens in the Tengger highland (East Java, Indonesia) and its importance for regional ecotourism planning. Hikobia 15(1), 23-26.

[8] Turner, N. J. 1988. The importance of a rose: evaluating the cultural significance of plants in Thompson and Lillooet Interior Salish. Royal British Columbia Museum. British.

[9] Batoro, J. 2015. Pengelolaan lingkungan dengan pendekatan etnobiologietnobotani. Universitas Brawijaya Press. Malang.

[10] Chen, D., W. Wei and L. Chen. 2017. Effects of terracing practices on water erosion control in China: A meta-analysis. EarthScience Reviews 173, 109-121.

[11] Jayasinghe, M., A. Chai, S. Ratnasiri and C. Smith. 2017. The power of the vegetable patch: How home-grown food helps large rural households achieve economies of scale and escape poverty. Food Policy 73, 62-74.

[12] DebMandal and S. Mandal, 2011. Coconut (Cocos nucifera L.: Arecaceae): In health promotion and disease prevention, Asian Pacific Journal of Tropical Medicine 4(3), 241-247.

[13] George, E., K. Ramalakshmi and L. J. M. Rao. 2008. A perception on health benefitsof coffee. Critical Reviews in Food Science and Nutrition 48(5), 464-486. 